\title{
基于知识图谱的中医药一带一路发展现状分析
}

\author{
焦宏官 ${ }^{1}$, 丁然 ${ }^{1}$,, 奚锦 $^{1}$, 徐俊 $^{2}$ \\ 1贵州中医药大学, ${ }^{2}$ 中国中医科学院中医药信息研究所
}

\section{Analysis of the Development of Traditional Chinese Medicine on the Belt and Road Based on Knowledge Map}

\author{
Jiao Hongguan ${ }^{1}$, Ding $\operatorname{Ran}^{1, *}, \mathrm{Xi} \mathrm{Jin}^{1}, \mathrm{Xu} \mathrm{Jun}^{2}$ \\ ${ }^{1}$ Guiyang College of Traditional Chinese Medicine, Guiyang, ${ }^{2}$ Institute of Information on Traditional Chinese Medicine Library, CACMS, \\ Beijing, China
}

\section{Received September 27, 2021 \\ Revised September 30, 2021 \\ Accepted September 30, 2021 \\ *Corresponding Author \\ Ding Ran \\ Guiyang College of Traditional Chinese Medicine, No.50 Shidonglu, Guiyang, Guizhou, China \\ Tel: +86-851-5928633 \\ Fax: +86-851-5928633 \\ E-mail: dingran95@126.com}

基金: 国家中医药管理局2019年国际 合作专项, 项目名称: 东盟国家中医药 民族医药文化传播示范研究; 项目编号: GZYYGJ2019055.

贵阳中医学院博士启动基金, 编号:

2017JHG.
Based on CNKI as the data source, this paper applies the knowledge map analysis method in information metrology to analyze the development status of Chinese medicine along the belt and the road, and analyzes the overall situation of related papers in the area of Chinese medicine, such as the whole volume distribution, annual distribution of articles, the author's cooperative network analysis, and institutional cooperation network analysis, etc. at the same time, it applies the CiteSpace developed by Professor Chaomei Chen from Drexel University of the United States. Based on the co-occurrence cluster analysis, it is found that the current development of Chinese medicine is a stage of diversification and flourishing, and cooperation and development from research, education, business and other fields.

Keywords: Traditional Chinese medicine, The belt and the road, Status, CiteSpace, Knowledge map

\section{摘要}

本文以中国知网为数据来源应用信息计量学中知识图谱 分析方法对中医药一带一路发展状况进行分析, 分析中医药 一带一路相关论文的整体情况如整理发文量, 年发文量分布, 作者合作网络分析，机构合作网络分析等信息，同时应用美 国德克赛尔大学陈超美教授开发的CiteSpace对数据关键词 进行共现聚类分析, 发现目前中医药一带一路发展现状是发 展多样化并处于百花齐放并逐渐走向成熟的阶段, 从科研, 教育, 商贸等各个领域开展合作与开发。

关键词: 中医药, 一带一路, 现状, CiteSpace, 知识图谱

\section{背景}

我国自2013年首次提出“一带一路”战略以来, 中医药国际 化一带一路国家范围发展取得了积极的进展。2016年2月, 国 务院印发《中医药发展战略规划纲要(2016-2030年)》1), 提出 实施“一带一路”和“走出去”战略, 急需推动中医药海外创新 发展。2016年10月, 《健康中国2030规划纲要》年发布, 指示以 双边合作机制为基础, 创新合作模式, 加强人文交流, 促进我 国与“一带一路”沿线国家卫生合作。2016年底, 国家中医药 局, 国家发改委联合印发《中医药“一带一路”发展规划(20162020年)》以来 ${ }^{2)}$, 全面部署了中医药对外开放新格局。“一带一 路”中医药国际合作模式彰显了互帮互助, 公平合理, 互惠互 利的国际经济合作新方式，促进第3世界国家间的经济交流 
与发展, 为国际经济合作新秩序构建和中医药国际化发展提 供了有益帮助。随着“一带一路”与“健康中国”国家战略和规 划的提出，《中华人民共和国中医药法》也于 2016 年底正式出 台, 并在2017年7月1日正式施行。中医药已上升到国家层面 的整体健康战略。中国和“一带一路”沿线国家进行医药产业 合作是时代发展的需要 2 。

随着中医药事业在一带一路方向发展相关的国家政策法 规文件出台, 涉及中医药在一带一路方面发展的相关研究逐 渐增加, 本文以中国知网(CNKI)为数据来源, 对中医药一带 一路相关的研究做一个以知识图谱演变过程和合作团队角 度的文献计量学分析。以期达到把握中医药一带一路发展状 况及提出决策建议的目的。

\section{数据来源及检索式}

本文对CNKI中相关中医药一带一路话题的期刊论文题录

\section{年出版文献量}

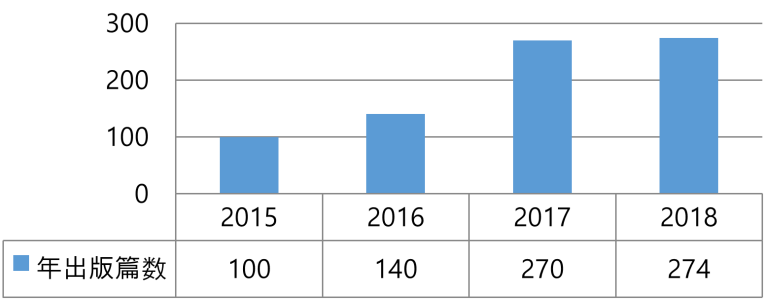

Figure 1. 中医药一带一路年出版文献量.
进行分析。

1. 检索式

以“一带一路”以及中医药(“中医”OR“中药”OR“针炎” OR “中医药”)相关主题为关键词进行主题检索, 检索时间不限, 检索日期为2019年1月1日。

检索出394篇相关文献。

\section{数据总体情况}

\section{1. 每年出版相全论文篇数}

从可以看出, 有关中医药一带一路的文章从 2015 年的 100 篇开始到2018年的274篇是逐年增长的过程, 这显示中医药

\section{期刊来源}

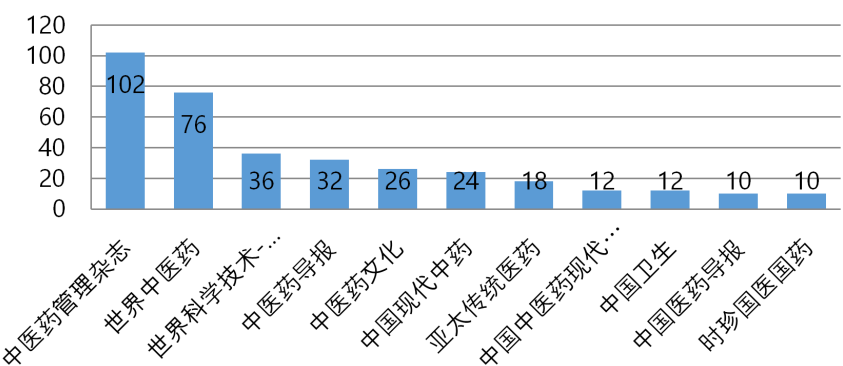

Figure 2. 中医药一带一路论文期刊分布.

Table 1. 刊载中医药一带一路排名前30的期刊

\begin{tabular}{|c|c|c|c|c|c|}
\hline 序号 & 期刊来源 & 记录数 & 序号 & 期刊来源 & 记录数 \\
\hline 1 & 中医药管理杂志 & 102 & 16 & 广西中医药大学学报 & 8 \\
\hline 2 & 世界中医药 & 76 & 17 & 世界中西医结合杂志 & 6 \\
\hline 3 & 世界科学技术-中医药现代化 & 36 & 18 & 中医杂志 & 6 \\
\hline 4 & 中医药导报 & 32 & 19 & 中医研究 & 6 \\
\hline 5 & 中医药文化 & 26 & 20 & 中华中医药杂志 & 6 \\
\hline 6 & 中国现代中药 & 24 & 21 & 中国中药杂志 & 6 \\
\hline 7 & 亚太传统医药 & 18 & 22 & 中国中西医结合杂志 & 6 \\
\hline 8 & 中国中医药现代远程教育 & 12 & 23 & 前进论坛 & 6 \\
\hline 9 & 中国卫生 & 12 & 24 & 商业文化 & 6 \\
\hline 10 & 中国医药导报 & 10 & 25 & 大众科技 & 6 \\
\hline 11 & 时珍国医国药 & 10 & 26 & 当代经济 & 6 \\
\hline 12 & 中医教育 & 8 & 27 & 西部中医药 & 6 \\
\hline 13 & 中医药通报 & 8 & 28 & 世界最新医学信息文摘 & 4 \\
\hline 14 & 中国针炎 & 8 & 29 & 中医临床研究 & 4 \\
\hline 15 & 全国新书目 & 8 & 30 & 中医健康养生 & 4 \\
\hline
\end{tabular}


一带一路受关注程度是在逐渐增加的。

\section{2. 检索出的394篇论文分布在168中不同期刊来源。}

从期刊来源上来看(图表 2),《中医药管理杂志》以102篇 占据发文量第一的期刊位置；《世界中医药》位居第二名,《世 界科学技术-中医药现代化》名列第三, 其他发文量大于10的 期刊(位列排名前 11 位的期刊)有《中医药导报》《中医药文化》 《中国现代中药》《亚太传统医药》《中国中医药现代远程教育》 《中国卫生》《中国医药导报》《时珍国医国药》。可以证明中医 药一带一路相关研究受到很大的重视。

\section{3. 刊文排名靠前的期刊}

\section{4. 期刊刊载文献随着年代的变化(刊登10篇以上期刊)}

从图可以看出,《中医药管理杂志》可以说是嗅觉灵敏, 在 最初的2015年就刊载了相关论文, 《世界中医药》近几年相关 论文发文量是快速增长的过程，《世界科学技术一中医药现代 化》在2017年有一个井喷式增长, 达到26篇, 说明该刊对这 一话题的关注; 《中国中医药现代远程教育》从最初很少的发 文量到2018年快速增长说明了中医药远程教育在中医药一 带一路中将发挥重要作用。

《中医药管理杂志》以102篇占据发文量第一的期刊位置；
《世界中医药》位居第二名, 《世界科学技术-中医药现代化》名 列第三, 其他发文量大于10的期刊(位列排名前 11 位的期刊) 有《中医药导报》《中医药文化》《中国现代中药》《亚太传统医 药》《中国中医药现代远程教育》《中国卫生》《中国医药导报》 《时珍国医国药》。可以证明中医药一带一路相关研究受到很 大的重视。

\section{5. 高发文作者}

\section{6. 发文4篇以上的机构}

上海中医药大学发文 44 篇, 位居第一名, 这与上海有深厚 的国际化城市有关; 世界中医药学会联合会发文 44 篇, 名列 第二, 该学会相应国家号召, 积极地以实际行动参与到中医 药一带一路的传播工作中来; 湖南中医药大学发文32篇, 而 且主要集中在2017年, 这说明该大学对中医药一带一路研究 于2017年掀起了一个高潮, 但是到了2018年有急剧减少, 这 可能跟政策缺乏延续性有关; 陕西中医药大学发文30篇, 与 其作为丝绸之路的地缘优势近几年持续地增长; 紧随其后的 还有北京中医药大学发文26篇, 南京中医药大学发文26篇, 广西中医药大学发文 20 篇, 云南中医学院发文 18 篇, 中国中 医科学院发文 16 篇, 广州中医药大学发文 16 篇, 湖北中医药 大学发文 16 篇, 河南中医药大学发文 14 篇, 甘肃中医药大学 发文12篇。

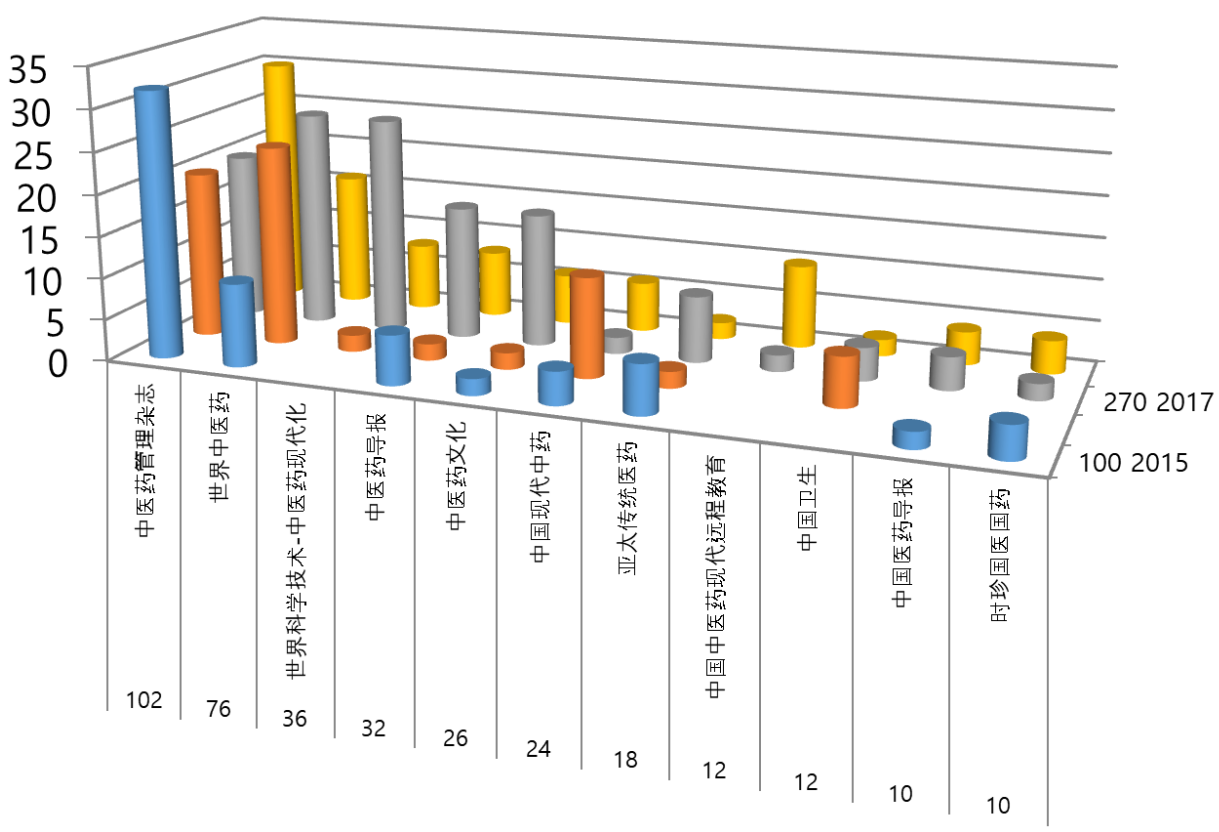

1002015

1402016

2702017

2742018

Figure 3. 期刊刊载文献随着年代的变化. 
Jiao Hongguan, et al.

Table 2. 发文4篇以上作者

\begin{tabular}{|c|c|c|c|c|c|}
\hline 序号 & 发表篇数 & 作者 & 序号 & 发表篇数 & 作者 \\
\hline 1 & 20 & 严暄暄 & 39 & 4 & 周青 \\
\hline 2 & 20 & 宋欣阳 & 40 & 4 & 唐红珍 \\
\hline 3 & 14 & 赵维婷 & 41 & 4 & 孙永林 \\
\hline 4 & 12 & 何清湖 & 42 & 4 & 孟方琳 \\
\hline 5 & 12 & 周蔓仪 & 43 & 4 & 左媛媛 \\
\hline 6 & 12 & 陈小平 & 44 & 4 & 张晓东 \\
\hline 7 & 10 & 朱民 & 45 & 4 & 张晓燕 \\
\hline 8 & 8 & 卡跃峰 & 46 & 4 & 张洪雷 \\
\hline 9 & 8 & 张丽 & 47 & 4 & 张继苹 \\
\hline 10 & 8 & 施建蓉 & 48 & 4 & 张㳼华 \\
\hline 11 & 8 & 本刊编辑部 & 49 & 4 & 慕秀荣 \\
\hline 12 & 8 & 省培根 & 50 & 4 & 曲姗姗 \\
\hline 13 & 8 & 郑林牎 & 51 & 4 & 李欣 \\
\hline 14 & 6 & 丁颖 & 52 & 4 & 李绵绵 \\
\hline 15 & 6 & 刘丹 & 53 & 4 & 李霞 \\
\hline 16 & 6 & 司富春 & 54 & 4 & 梁晓兰 \\
\hline 17 & 6 & 张炎 & 55 & 4 & 毛和荣 \\
\hline 18 & 6 & 曲俵俵 & 56 & 4 & 汤少梁 \\
\hline 19 & 6 & 本刊讯 & 57 & 4 & 田林 \\
\hline 20 & 6 & 李海英 & 58 & 4 & 申俊龙 \\
\hline 21 & 6 & 李红文 & 59 & 4 & 白吉庆 \\
\hline 22 & 6 & 杨宇洋 & 60 & 4 & 章涤凡 \\
\hline 23 & 6 & 王硕 & 61 & 4 & 胡检生 \\
\hline 24 & 6 & 胡以仁 & 62 & 4 & 荆伟龙 \\
\hline 25 & 6 & 胡彬 & 63 & 4 & 葛伟蹈 \\
\hline 26 & 6 & 魏敏 & 64 & 4 & 赵少钦 \\
\hline 27 & 6 & 黄璐琦 & 65 & 4 & 赵文 \\
\hline 28 & 4 & 于志斌 & 66 & 4 & 赵立春 \\
\hline 29 & 4 & 何兰萍 & 67 & 4 & 郑扬康 \\
\hline 30 & 4 & 侯冠辉 & 68 & 4 & 顾赤 \\
\hline 31 & 4 & 侯荔桉 & 69 & 4 & 马静 \\
\hline 32 & 4 & 储利荣 & 70 & 4 & 骆璐 \\
\hline 33 & 4 & 冯雅婷 & 71 & 4 & 高山 \\
\hline 34 & 4 & 刘彦臣 & 72 & 4 & 魏一苇 \\
\hline 35 & 4 & 刘殿刚 & 73 & 4 & 魏浩然 \\
\hline 36 & 4 & 刘洁 & 74 & 4 & 黄泳 \\
\hline 37 & 4 & 向佳 & 75 & 4 & 黄祎晨 \\
\hline 38 & 4 & 吴非 & 76 & 4 & 黄静婧 \\
\hline
\end{tabular}

\section{7. 机构发文随年代的变化}

从图 4来看, 中医药一带一路相关论文发文机构是以国内
中医药大学等高校和科研机构为主, 民间的世界中医药学会 联合会在这里独树一帜, 考虑跟该学会积极举办各种相关会 议有关。 
Table 3. 发文4篇以上的机构

\begin{tabular}{|c|c|c|}
\hline 序号 & 篇数 & 机构名称 \\
\hline 1 & 44 & 上海中医药大学 \\
\hline 2 & 44 & 世界中医药学会联合会 \\
\hline 3 & 32 & 湖南中医药大学 \\
\hline 4 & 30 & 陕西中医药大学 \\
\hline 5 & 26 & 北京中医药大学 \\
\hline 6 & 26 & 南京中医药大学 \\
\hline 7 & 20 & 广西中医药大学 \\
\hline 8 & 18 & 云南中医学院 \\
\hline 9 & 16 & 中国中医科学院 \\
\hline 10 & 16 & 广州中医药大学 \\
\hline 11 & 16 & 湖北中医药大学 \\
\hline 12 & 14 & 河南中医药大学 \\
\hline 13 & 12 & 甘肃中医药大学 \\
\hline 14 & 8 & 《中医药导报》杂志社 \\
\hline 15 & 6 & 《中医药文化》编辑部 \\
\hline 16 & 6 & 世界针炎学会联合会 \\
\hline 17 & 6 & 中国医药保健品进出口商会 \\
\hline 18 & 6 & 福建中医药大学 \\
\hline 19 & 4 & 《中国当代医药》 \\
\hline 20 & 4 & 上海杉达学院商学院 \\
\hline 21 & 4 & 东华大学管理学院 \\
\hline 22 & 4 & 中国传媒大学博士后流动站 \\
\hline 23 & 4 & 中国医学科学院北京协和医学院药用植物研究所 \\
\hline 24 & 4 & 井冈山大学医学部 \\
\hline 25 & 4 & 全国政协 \\
\hline 26 & 4 & 南方医科大学中医药学院 \\
\hline 27 & 4 & 国家中医药管理局网站 \\
\hline 28 & 4 & 天津中医药大学国际教育学院 \\
\hline 29 & 4 & 宁夏医科大学中医(回医)学院 \\
\hline 30 & 4 & 湖北省高校人文社会科学重点研究基地中医药发展研究中心 \\
\hline 31 & 4 & 贵阳中医学院 \\
\hline 32 & 4 & 辽宁中医药大学 \\
\hline 33 & 4 & 长春中医药大学 \\
\hline 34 & 4 & 黑龙江中医药大学 \\
\hline
\end{tabular}

\section{CiteSpace矣键词聚类图}

CiteSpace ${ }^{3,4}$ 是美国德克赛尔大学陈超美教授基于Java语 言开发的可视化软件, 该软件不仅能挖掘引文空间的知识聚 类和分布，而且还提供其他知识单元之间的共现分析功能, 如作者, 机构, 国家之间的合作等团。

将数据进行初步处理, 转换后导入到CiteSpace中分析。
将 1 年设置为一个时间片段(slice), 选取关键词和作者机 构为节点类型, 关键词用三角形表示, 作者机构用圆形表示, 以年轮的方式展示节点的大小, 节点越大表示该词或机构的 频次越高, 越是研究的关注点或者核心发文机构。链接关系 用cosine算法, 选取排名前 $40 \%$ 的关键节点。进行聚类分析, 结果显示模块值 $(\mathrm{Q}$ 值) 是 0.953 ; 平均轮廓值 $(\mathrm{S}$ 值) 是 0.6124 。 一般来说, 依据网络结构和聚类的清晰度, 提供了模块值 $(\mathrm{Q}$ 


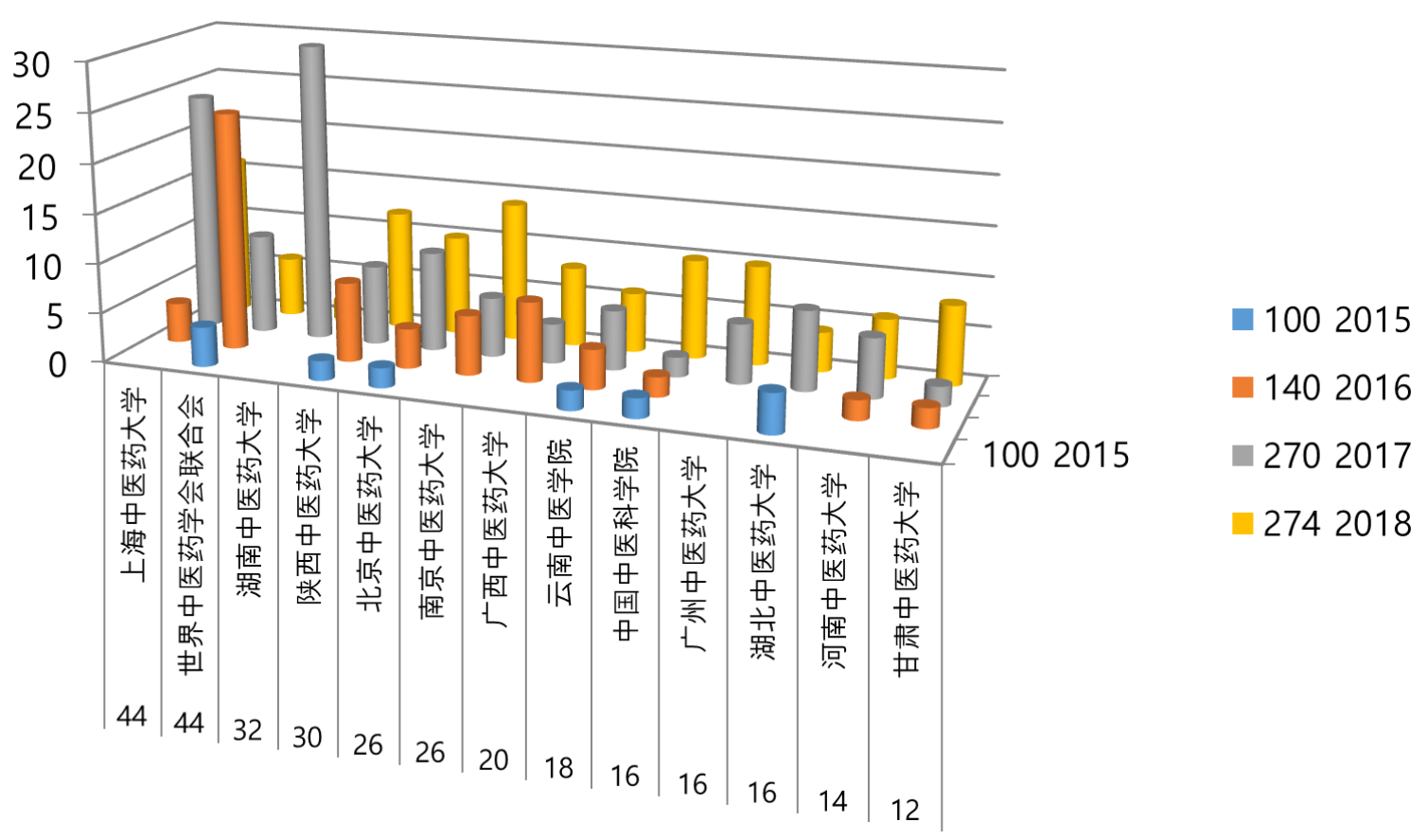

Figure 4. 机构发文随年代的变化.

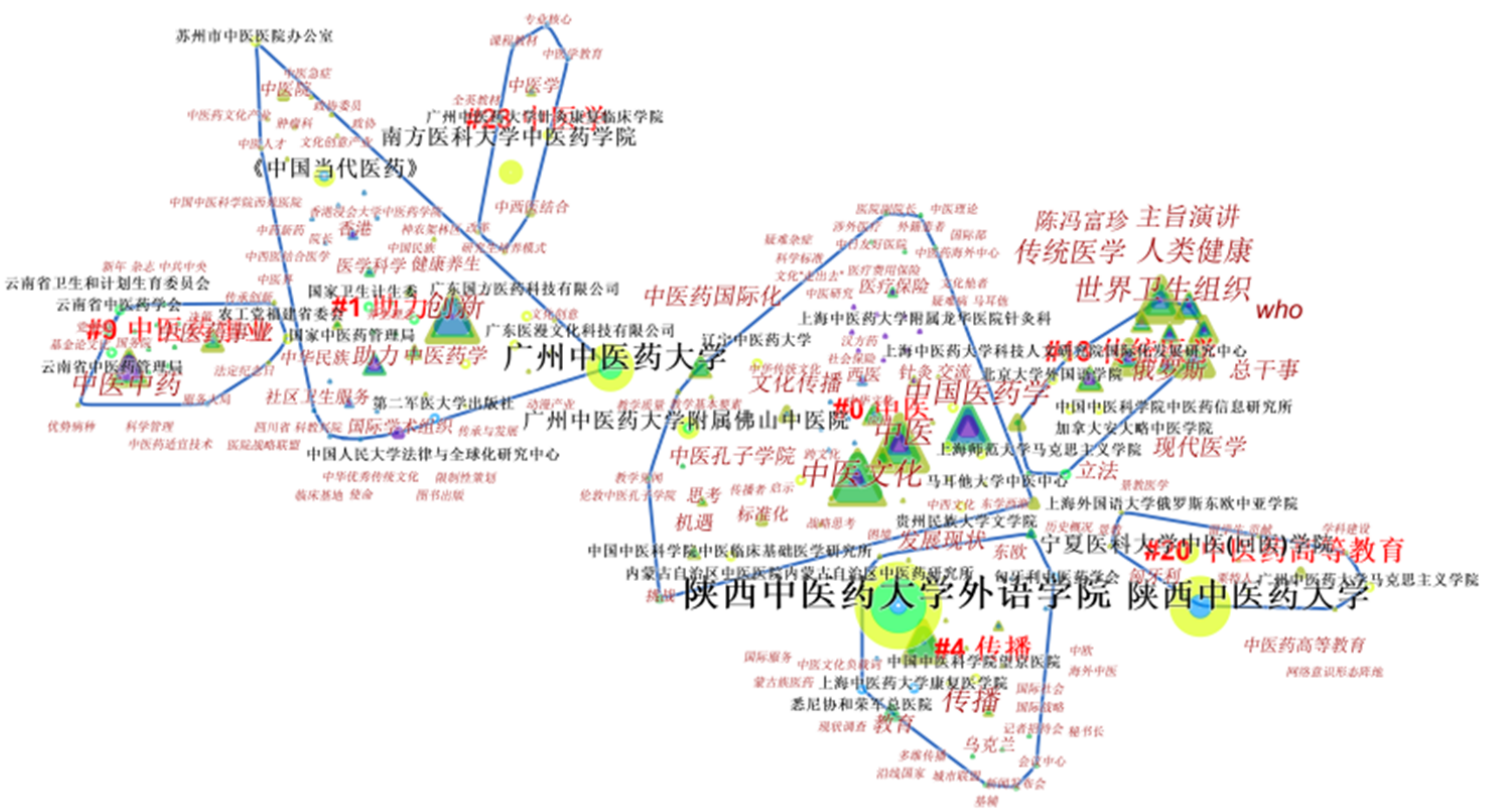

Figure 5. CiteSpace矣键词聚类图.

值)和平均轮廓值(S值)两个指标, 它可以作为我们评判图谱绘 制效果的一个依据。一般而言, Q值一般在([0-1])区间内, Q $>0.3$ 就意味着划分出来的社团结构是显著的, 当 $S$ 值在 0.7 时,
聚类是高效率令人信服的, 若在 0.5 以上, 聚类一般认为是合 理的。所以我们认为该聚类图是相对显著并令人信服的 ${ }^{5}$ 。

CiteSpace关键词聚类, 得到七个大类, 第一大类是以“中 
医”为聚类标签的由上海中医药大学, 广州中医药大学复数 佛山中医院，马耳他大学中医中心，辽宁中医药大学等机构 主导的, 以中医, 孔子文化传播为主题的聚类, 主要从文化传 播, 中西文化交融为研究方向, 这是有关中医药一带一路的 主要研究主题, 其中提及了机遇, 困境, 思考, 标准化, 针炎, 医疗保险, 发展现状等具体操作过程中的理论探讨 ; 第二大 类是以“助力”为标签的有国家中医药管理局, 广州中医药大 学, 国家卫生计生委, 以及一些广东的医药文化公司为主导, 围绕着中医院，中医药文化产业，中华民族，中医药学，中医 药学院为主题方向的聚类, 该聚类沟通了中国政府与香港以 及广东地区与香港的地缘优势建立的传播途径 ; 第三大类 是以“传播”为聚类标签的以陕西中医药大学外语学院, 中国 中医科学院望京医院, 上海中医药大学康复医学院, 悉尼协 和荣军总医院等机构为主导, 以国际传播, 国际服务, 国际战 略, 海外中医, 多维传播, 会议中心, 记者招待会, 教育等为主 题的聚类, 主要开展地区是中欧, 乌克兰等地; 第四大类是 以“中医药事业”为聚类标签, 由云南省中医药学会, 与男生中 医药管理局, 与男生卫生和计划生育委员会为主导的, 以中
医药事业, 优势病种, 传承创新等为主题的聚类; 第五类是 以“传统医学”为聚类标签, 以北京大学外国语学院, 上海中医 药大学科技人文研究员国际化发展研究中心, 中国中医科学 院中医药信息研究所, 加拿大安大略中医学院等机构为主导 的以传统医学, 国际卫生组织, 人类健康等宏观角度去探讨 中医药一带一路的研究; 第六类是以“中医药高等教育”为聚 类标签, 由广州中医药大学马克思主义学院, 陕西中医药大 学, 宁夏医科大学中医(回医)学院, 上海外国语大学俄罗斯东 欧中亚学院等机构为主导的, 以中医药高等教育, 网络意识 形态阵地, 学科建设, 留学生贡献等为研究方向的聚类; 第 七类是以“中医学”为聚类标签以广州中医药大学针尒康复临 床学院, 南方医科大学中医学院为主导的, 以中医学, 中医学 教育, 专业核心, 课程教材, 全英教材, 中西医结合等学科建 设的角度的聚类。

\section{9. 机构合作网络}

从图 6可以看出，机构间的合作可以大致分为五个团队,
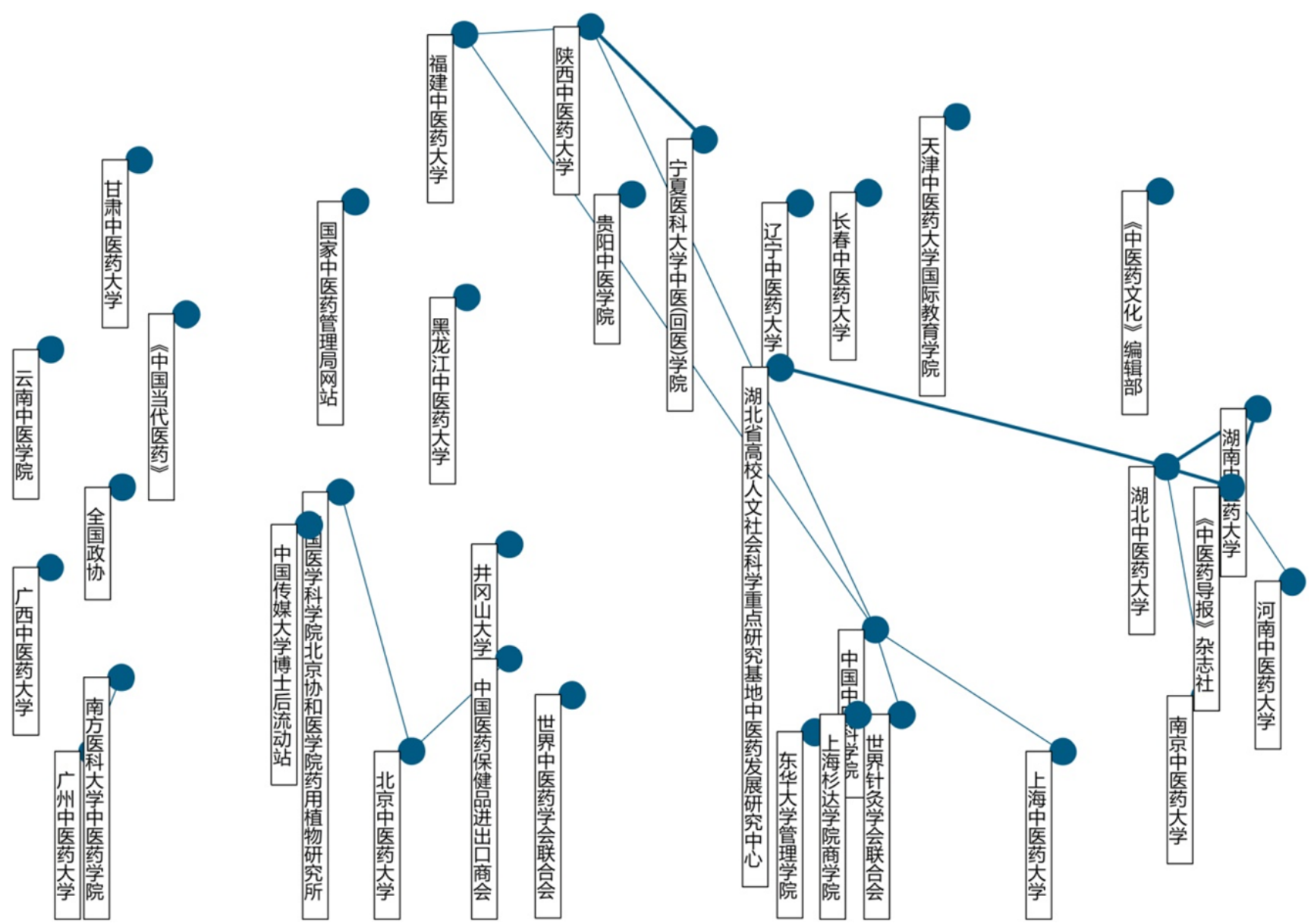

Figure 6. CiteSpace兊键词聚类图. 
首先是斜跨最上端中间和右下的巨大团队，上端中间部分有 福建中医药大学, 山西中医药大学, 贵阳中医学院, 宁夏医科 大学, 辽宁中医药大学, 长春中医药大学, 天津中医药大学构 成的团队上半部分, 与之联系紧密的是下半部分的上海中医 药大学, 中国中医科学院, 师姐针尒学会联合会, 上海杉达学 院商学院, 东华大学管理学院, 这部分除了中国中医科学院 外都是滑动地区的机构, 显示了上海地区的地缘优势和国际 化程度较高的优势。其次是该团队右侧的湖北中医药大学, 湖南中医药大学, 中医药导报杂志社(湖南), 河南中医药大 学, 南京中医药大学以及湖北省高校人文社会科学重点研究 基地中医药发展研究中心(武汉工商学院)构成的华中华南地 区团队。另外一个团队是北京中医药大学, 世界中医药学会 联合会, 中国医药保健品进出口商会, 中国医学科学院北京 协和医学院要用植物研究所和中国传媒大学不是后流动站 组成的北京团队。最左侧下端是由广州中医药大学, 南方医 科大学中医药学院, 广西中医药大学, 云南中医学院等机构 组成的两广和西南地区的较松散的合作团队。

\section{0. 作者合作网络}

发文大于等于 4 篇论文的作者有 76 位, 发文大于等于 10 篇 的作者分别是：严暄暄发文 20 篇, 宋欣阳发文 20 篇, 赵维婷 发文 14 篇, 何清湖发文 12 篇, 周蔓仪发文 12 篇, 陈小平发文 12篇, 朱民发文 10 篇。

从作者自相关聚类图来看, 排名靠前的76位作者构成几个 比较大的团队, 比如右侧最大团队, 有作者严暄暄, 何清湖, 胡以仁, 陈小平, 朱民, 丁颖, 魏一苇, 李红文, 刘洁, 冯雅婷, 主要由高发文作者构成; 其次的团队是右下角的团队, 有宋 欣阳, 李海英, 市跃峰, 施建蓉, 郑林望, 黄神晨, 魏浩然, 王 硕; 左侧几个小型团队其中比较大的一个团队是由吴非, 左 媛媛, 赵少钦, 周青, 孙永林组成; 左下有三个小团队分别是 刘丹, 张鹭华, 胡检生组成; 曲姗姗, 张继苹, 黄泳组成的第 二支团队, 以及杨宇洋, 骆璐组成的第三支小团队 ; 左上是 黄璐琦, 白吉庆, 肖培根, 赵立春, 唐红珍, 梁晓兰等组成的较 大一支团队 ; 左中是由章涤凡, 刘殿刚, 张晓燕, 顾赤, 毛和
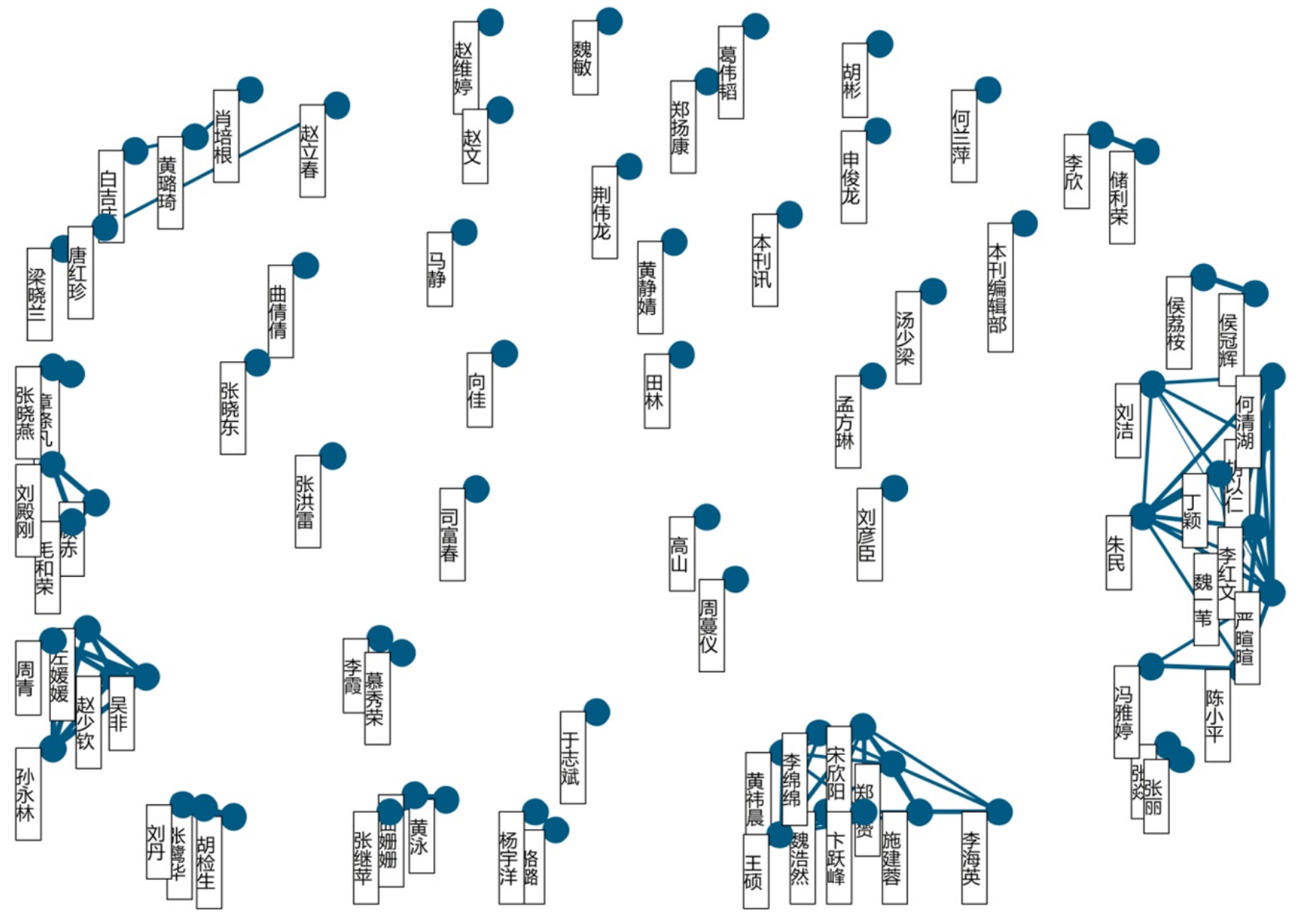

Figure 7. 作者自相爸地图. 
荣等组成的团队。其他排名靠前的作者如张炎和张丽, 李欣 和储利荣, 侯冠辉和侯荔桉, 慕秀荣和李霞组成的二人团队, 其余的高产量作者以个人产出为主, 未形成明显的团队。

\section{总结}

纵观中医药一带一路的发展状况, 不难发现, 目前该领域 的研究方向正处于百花齐放并逐渐走向成熟的阶段, 也是八 仙过海各显神通的时代。有遵循历史上中医药国际化, 国际 贸易, 国际合作的讨论, 比如与发达国家在科研, 药物开发等 领域开展国际合作 ${ }^{6-12)}$ 。也有以中医药文化, 中国传统文化传 播为主要方式的“走出去”战略的应用 ${ }^{13-17)}$, 同时有中医药高 等教育方面的研究 ${ }^{18-23)}$, 以及中医中心的建立 ${ }^{24)}$ 和中医医院 应对一带一路视域下的发展战略 ${ }^{25-27)}$, 加强中医药标准的研 制工作 ${ }^{28-31)}$, 中医药国际服务贸易的发展 ${ }^{32-38)}$, 一带一路背景 下的中医药国际人才培养, 其中包括国内中医药人才培养和 海外留学生的中医药人才培养 ${ }^{25,39-48)}$ 。

目前中医药一带一路发展方向相对多样化, 从国家, 政府 宏观的角度出发, 国家鼓励, 支持中医药借着一带一路的政 策优势走出去, 为世界地区经济发展做出自己的贡献, 从中 观的角度来看, 国内各个中医药院校和研究机构正在积极大 力开发中医药一带一路项目; 从微观的角度来看, 有越来越 多的医务, 科研, 教学人员参与到中医药一带一路项目中来。

在中医药一带一路发展道路上, 目前正在积极解决由谁 做一一中医药国际化人才培养, 做什么一一科研, 商贸, 医 疗, 养生保健, 文化传播 ; 为什么一一实现“和平合作, 开放 包容, 互学互鉴, 互利共赢” ${ }^{29}$ 的一带一路。相信中医药以其独 特的文化, 健康, 医疗, 保健等的载体优势, 必将成为一带一 路上的一朵奇苑。

\section{FUNDING}

Doctoral Start-up Fund of Guiyang University of Chinese Medicine.

\section{参考文献}

1. 贾瑞婷, 六跃峰, 宋欣阳, 等. “互联网+中医”发展现状及应用 [J]. 中华中医药杂志, 2018, 33(09)：3852-5.

2. 张如霞, 汤少梁. “一带一路”进程中中医药国际合作机制研究 [J]. 中草药, 2018, 49(07): 1726-32.

3. CHEN C, CHEN Y, HOU J,等. CiteSpace I : detecting and visualizing emerging trends and transient patterns in scientific literature [J]. Journal of the China Society for Scientific and Technical Information, 2009, 28(3): 401-
21.

4. PING Q, HE J, CHEN C. How Many Ways to Use CiteSpace? A Study of User Interactive Events Over 14 Months [J]. Journal of the Association for Information Science and Technology, 2017, 68(5): 1234-56.

5. 陈悦, 陈超美, 刘则渊,等. CiteSpace知识图谱的方法论功能 [J]. 科学学研究, 2015, 33(02): 242-53.

6. 六跃峰, 魏浩然, 宋欣阳. 中医药对外交流合作示范基地发展策略 研究 [J]. 世界中西医结合杂志, 2017, 12(12): 1752-5.

7. 曾林, 陈本, 张杰. “一带一路”战略视野下加强云南与东盟国家中 医药合作交流的探讨 [J]. 广西医学, 2017, 39(04): 580-2.

8. 黄岗. 俄罗斯与毕节合作开发中医药事业 [J]. 中国农村卫生, 2015, 13): 31

9. 黄祎晨, 李绵绵, 宋欣阳, 等. 中医药参与国际医疗多边合作策略 分析 [J]. 中医药导报, 2017, 23(17): 7-9+18.

10. 孙银屏, 胡凯文, 王伊光, 等. 我国“一带一路”倡议背景下中医药国 际合作交流平台构建初探 [J]. 中国医药导报, 2017, 14(22): 848.

11. 唐红珍, 梁晓兰. 加快中医保健文化“走出去” 助推“一带一路”建 设一一以中国与东盟合作为中心的研究 [J]. 东南亚纵横, 2018, 04): 91-5.

12. 张诗钰, 黄建元, 申俊龙, 等. “一带一路”战略背景下中医药国际化 区域合作的路径选择与策略优化 [J]. 中国卫生事业管理, 2017, 34(03): 172-6.

13. 陈小平, 冯雅婷, 王歆妍, 等。“带一路”战略视域中的中医文化智 库研究 [J]. 世界科学技术-中医药现代化, 2017, 19(06): 98993.

14. 黄静婧. 论“一带一路”背景下广西中医药文化的对外传播 [J]. 广 西中医药大学学报, 2017, 20(04): 90-2.

15. 李红文, 严暄暄, 沙凯歌. “一带一路”战略背景下中医药文化的传 播策略与路径 [J]. 世界科学技术-中医药现代化, 2017, 19(06): 984-8.

16. 刘殿刚, 毛和荣, 顾赤. “一带一路”战略视野下湖北中医药文化对 外传播研究 [J]. 时珍国医国药, 2015, 26(08): 1961-3.

17. 邰东梅, 郭力铭, 孙迪. 坚定文化信念, 讲好中医故事一一斯洛伐克 “中医孔子学院”课程体系建设与实践 [J]. 辽宁中医药大学学报, 2018, 20(08): 130-2.

18. 陈云慧, 田芷柠, 张天娥, 等. “一带一路”背景下推动中医经典教育 走出去的几点思考 [J]. 成都中医药大学学报(教育科学版), 2018, 20(03): $1-2+16$.

19. 方否, WANG B. 澳大利亚中医药发展现状调查及对中医药国际 化教育与传播的思考 [J]. 中医药文化, 2016, 11(03): 24-8.

20. 胡迪. 高等中医药院校思想政治教育在中医药文化对外传播中的功 能探究 [J]. 智库时代, 2017, 10): 141-2.

21. 蒋剑锋, 李俊伟. 一带一路战略下中医药国际教育的战略转型 [J]. 
中国高等医学教育, 2016, 06): 26-7.

22. 吴帆, 朱庆龙, 欧德先. 文化自觉与文化自信:中医药文化教育的新 视角 [J]. 课程教育研究, 2017, 51): 238-9.

23. 易亚乔, 喻嵘, 杨丽, 等. “一带一路”战略视角下浅析中医药教育国 际化发展之路 [J]. 世界科学技术一中医药现代化, 2017, 19(06): 1016-20.

24. 何艺韵, 宋欣阳, 李海英, 等. “一带一路”视域下中医药海外中心发 展策略 [J]. 中医杂志, 2018, 59(12): 997-1001.

25. 江云, 马俊坚, 朱梅萍,等. 研究型中医院中医药国际化人才综合评 价指标体系的初探 [J]. 上海中医药杂志, 2016, 50(S1): 31-4.

26. 姜萌, 张继红, 徐丙元. “一带一路”视域下高等中医院校传播中医 药文化的探究-一以思想政治教育为载体 [J]. 中医药管理杂志, 2018, 23): 1-3.

27. 姚月明. 中医院走向“一带一路”的国际化策略分析 [J]. 江苏卫生事 业管理, 2018, 29(05): 495-7+529.

28. 安江. “一带一路”倡议背景下的我国中医药标准化发展研究 [J]. 中 国药事, 2018, 32(09): 1167-71.

29. 韩学杰, 王丽颖, 王跃溪等. 以“一带一路”为契机,推进标准化助力 中医药事业发展的战略思考; proceedings of the 标准化助力供 给侧结构性改革与创新一一第十三届中国标准化论坛, 中国山东 济南, F, 2016 [C].

30. 李明, 周强, 杨丽娜, 等. 中医症状术语标准研究的文献计量分析 [J]. 中国中医基础医学杂志, 2017, 23(02): 218-20.

31. 王跃溪, 刘玉祁, 王丽枈, 等. 中医药标准化发展迎来新的机遇与挑 战 [J]. 中华中医药杂志, 2018, 33(06): 2252-4.

32. 白琦瑶, 侯胜田, 袁剑, 等. “一带一路”战略下中医药服务贸易的发 展机遇与对策 [J]. 世界中医药, 2018, 13(02): 488-91.

33. 崔圆月, 胡凌娟, 孟浩婷. “一带一路”倡议下的中医药服务贸易 [J]. 中国医药导报, 2018, 15(04): 108-12.

34. 罗中华, 梁婷, 张翔, 等. 推动甘肃省中医药服务贸易发展策略研究 [J]. 中国中医药信息杂志, 2017, 24(01): 15-9.
35. 孟方琳, 贾巧萍. 产业融合视角下中医药服务贸易发展策略研究 [J]. 上海经济, 2018, 05): 19-32.

36. 吴洁婷. 国家“一带一路”倡议下中医药经济贸易的分析及对策研 究 [J]. 中医药临床杂志, 2018, 30(09): 1588-93.

37. 许海清. “一带一路”战略背景下中医药服务贸易发展的思考 [J]. 北 方经济, 2015, 05): 38-40.

38. 杨逢柱, 王芳. 中医药国际服务贸易发展战略刍议一一以“一带一 路”为例 [J]. 湖南科技学院学报, 2016, 37(04): 116-8.

39. 方宇. 高等院校中医药专业英语翻译人才培养模式研究 [J]. 现代 教育科学, 2017, 06): 100-3.

40. 黄炜, 文盈. 中医药人才跨文化素质内涵及其培养方式研究现状 [J]. 中国人力资源开发, 2013，19): 65-8.

41. 蒋剑锋. 推动人才国际流动 培养中医药国际化人才 [J]. 浙江中医 药大学学报, 2013, 37(02): 201-3.

42. 李欣. 中医药国际人才培养现状与策略分析 [J]. 中国继续医学教 育, 2017, 9(08): 52-4.

43. 李欣, 储利荣. “一带一路”视域下中医药国际人才培养问题研究 [J]. 中医药导报, 2017, 23(19): 1-3.

44. 王玨, 马新飞. “一带一路”背景下中医药国际化创业型人才培养模 式的思考 [J]. 中国药房, 2017, 28(33): 4741-4.

45. 王婷婷, 张丹英, 朱爽,等. “一带一路”国家来华留学中医高层次人 才培养的思考 [J]. 中医教育, 2017, 36(06): 65-7+70.

46. 谢粤湘. “一带一路”战略下中医药海外推广高层次商务人才的跨学 科协同培养机制思考 [J]. 湖北函授大学学报, 2017, 30(09): 36$7+42$.

47. 宿哲寒, 都晓春, 何占义. “互联网十一带一路”背景下中医药英语翻 译人才培养机制研究, Limassol,Cyprus, F, 2015 [C].

48. 杨毅, 曹立娅, 张胶. 中医药国际化人才培养的现状研究及对策分 析 [J]. 中国高等医学教育, 2010, 09): 5-7+13.

49. 任虎, 曹俊金. “一带一路”战略视域下的中药国际化研究 [J]. 科技 通报, 2016, 32(12): 57-61. 


\section{지식맵에 기초한 중의약 일대일로 발전 현황의 분석}

\section{번역: 최재훈}

\section{천안요양병원}

이 논문은 중국지망(CNKI)의 데이터를 원천으로 계량정보 학의 지식맵 분석 기법을 응용하여 중의약 일대일로의 발전 상 황을 분석하고, 중의약 일대일로 관련 논문의 전반적인 상황을 분석하며 발표한 논문의 양, 연간 논문 발표 양의 분포, 저자의 협업 네트워크를 분석하고 기관 합작 네트워크 분석 등의 정보 를 분석하는 한편, 미국 드렉셀대학교(Drexel University) 첸 차오메이(陈超美) 교수가 개발한 CiteSpace를 응용하여 데이 터 키워드를 Co-occurrence cluster 분석한 것으로 현재 중 의약 일대일로는 발전이 다양하고 백화제방(百花齊放)하며 점 차 성숙되는 단계에 있으며 과학연구, 교육, 무역 등 각 분야에 서 협력과 개발을 전개하고 있음을 발견하였다

키워드: 중의약, 일대일로, 현황, CiteSpace, 지식도보(지식맵)

\section{배경}

중국이 2013년 처음으로 "일대일로" 전략을 제창한 이래 중의약의 국제화 일대일로는 국가범위에서 발전하였고 적극적 인 진전을 보여왔다. 2016년 2월, 국무원이 발행한 《중의약발 전전략규획강요(中醫藥發展戰略規劃綱要) (2016-2030년)》에 서 “일대일로(一帶一路)”와 “저우추취(走出去)”를 실시할 것을 제시하면서 중의약이 해외로 진출하는데 있어 혁신적인 발전 이 요구되었다. 2016년 10월, 《건강중국2030규획강요 (健康 中國2030規劃綱要)》발표에서 쌍방향 협력을 기초로 협력 방식 을 혁신하고 인문교류를 강화하면서 중국과 “일대일로” 연선 국가의 위생부문과의 합작을 촉진할 것을 지시하였다. 2016년 말 국가중의약국(國家中醫藥局), 국가발전개혁위원회(國家發改 委)이 공동으로 《중의약“일대일로”발전규획(中醫藥“一帶一路” 發展規劃) (2016-2020년)》을 발표한 이래 중의약을 전면적으 로 외부로 개방하는 새로운 국면에 접어들었다. "일대일로"식 의 중의약의 국제협력은 상호원조, 공평합리, 호혜호리라는 국 제경제 협력의 새로운 방식으로 제3세계 국가간의 경제교류 와 발전을 촉진하여 국제경제 협력이라는 신질서를 구축하는 동시에 중의약의 국제화 발전에 유익한 도움을 제공하고 있다. “일대일로”와 “건강중국”이라는 국가전략과 규획에 따라 《중 화인민공화국중의약법(中華人民共和國中醫藥法)》역시 2016년 말 정식으로 공포되었고 2017년 7월 1일자로 정식 시행되었 다. 중의약이 이미 국가적 차원의 정체적(整體的) 건강 전략으
로 인정받은 것이며 중국과 “일대일로” 연선국가간 의약산업 의 협력은 시대적 발전의 요구이다.

중의약 사업의 일대일로 방향으로의 발전과 관련된 국가정 책법규문건이 발표되고 중의약의 일대일로 발전 방향에서의 관련 연구가 증가함에 따라 본 논문은 $\mathrm{CNKI}$ 를 데이터의 원천 으로 삼아 중의약 일대일로와 관련된 연구에 대해 지식맵에 기 반한 변천과 합작 단체 각도에서의 문헌을 계량학적으로 분석 하였다. 이는 중의약 일대일로의 발전 상황을 파악하고 정책을 건의하는데 목적이 있다.

\section{데이터의 원천 및 검색식}

본 논문은 $\mathrm{CNKI}$ 에서 중의약 일대일로와 관련된 저널 논문 에 대해 분석하였다.

\section{1. 검색식}

“一带一路” 및 중의약(“中医” or “中药” or “针炎” or “中医 药”) 관련 주제를 키워드로 하여 주제 검색을 하였다. 논문 발 표 시기는 한정짓지 않았으며 검색일시는 2019년 1월 1일이 다.

\section{데이터의 전체적 현황}

\section{1. 매년 출판되는 관련 논문 편수}

표에서 볼 수 있듯이 중의약 일대일로에 관련된 논문은 2015년에 100편으로 시작하여 2018년 274편까지 매년 점진 적으로 증가하고 있다. 이는 중의약 일대일로에 대한 관심이 점차 증가하고 있음을 보여준다.

\section{2. 검색된 394 편의 논문은 168 종의 서로 다른 정기간행물에 분 포되어 있다.}

표에서 볼 수 있듯이 《중의약관리잡지(中醫藥管理雜誌)》가 102편으로 가장 많으며 《세계중의약(世界中醫藥)》이 2번째, 《세계과학기술-중의약현 대화(世界科學技術-中醫藥現代化)》 가 3 번째이며 발표 논문이 10 편이 넘는 정기간행물로는 《중의 
약도보(中醫藥導報)》, 《중의약문화(中醫藥文化)》, 《중국현대중 약(中國現代中藥)》, 《아태전통의약(亞太傳統醫藥)》, 《중국중의 약현대원정교육(中國中醫藥現代遠程呚育)》, 《중국위생(中國衛 生)》, 《중국의약도보(中國醫藥導報)》, 《시진국의국약(時珍國醫 國藥》순으로 중의약 일대일로 관련 연구가 매우 중시되고 있 음을 알 수 있다.

\section{3. 중의약 일대일로 논문 수록 편수 상위 30 위 정기간행물}

\begin{tabular}{|c|c|c|}
\hline 순서 & 간행물 & 수록편수 \\
\hline 1 & 중의약관리잡지(中醫藥管理雜誌) & 102 \\
\hline 2 & 세계중의약(世界中醫藥) & 76 \\
\hline 3 & $\begin{array}{l}\text { 세계과학기술-중의약현대화 } \\
\quad \text { (世界科學技術-中醫藥現代化) }\end{array}$ & 36 \\
\hline 4 & 중의약도보(中醫藥導報) & 32 \\
\hline 5 & 중의약문화(中醫藥文化) & 26 \\
\hline 6 & 중국현대중약(中國現代中藥) & 24 \\
\hline 7 & 아태전통의약(亞太傳統醫藥) & 18 \\
\hline 8 & $\begin{array}{l}\text { 중국중의약현대원정교육 } \\
\text { (中國中醫藥現代遠程敎育) }\end{array}$ & 12 \\
\hline 9 & 중국위생(中國衛生) & 12 \\
\hline 10 & 중국의약도보(中國醫藥導報) & 10 \\
\hline 11 & 시진국의국약(時珍國醫國藥) & 10 \\
\hline 12 & 중의교육(中醫呚育) & 8 \\
\hline 13 & 중의약통보(中醫藥通報) & 8 \\
\hline 14 & 중국침구(中國鍼炎) & 8 \\
\hline 15 & 전국신서목(全國新書目) & 8 \\
\hline 16 & 광서중의약대학학보(廣西中醫藥大學學報) & 8 \\
\hline 17 & 세계중서의결합잡지(世界中西醫結合雜誌) & 6 \\
\hline 18 & 중의잡지(中醫雜誌) & 6 \\
\hline 19 & 중의연구(中醫硎究) & 6 \\
\hline 20 & 중화중의약잡지(中華中醫藥雜誌) & 6 \\
\hline 21 & 중국중약잡지(中國中藥雜誌) & 6 \\
\hline 22 & 중국중서의결합잡지(中國中西醫結合雜誌) & 6 \\
\hline 23 & 전진논단(前進論壇) & 6 \\
\hline 24 & 상업문화(商業文化) & 6 \\
\hline 25 & 대중과기(大衆科技) & 6 \\
\hline 26 & 당대경제(當代經濟) & 6 \\
\hline 27 & 서부중의약(西部中醫藥) & 6 \\
\hline 28 & 세계최신의학신식문적(世界最新醫學信息文摘) & 4 \\
\hline 29 & 중의임상연구(中醫臨床研究) & 4 \\
\hline 30 & 중의건강양생(中醫健康養生) & 4 \\
\hline
\end{tabular}

\section{4. 간행물에 게재된 문헌의 연도별 변화(10편 이상 등록된 정기 간행물)}

표 3 원문 참고.

표에서 보듯이 《중의약관리잡지》은 2015년 초반부터 관련 논문을 게재하여 ‘촉이 좋았다’고 말할 수 있으며 《세계중의약》 은 최근 들어 관련 논문 게재량이 급속도로 증가하고 있고 《세 계과학기술-중의약현대화》는 2017년 한해에만 폭발적으로 증가하여 게재한 논문이 무려 26편에 달하는 것을 보아 본 주 제에 관심이 집중되고 있음을 설명해준다. 《중국중의약현대원 정교육》의 경우 초기에는 매우 미미했으나 2018년에 이르러 발표 논문수가 급속도로 증가하는데 이는 중의약의 원격 교육 이 중의약 일대일로에 있어 중요한 역할을 하고 있음을 설명한 다.

《중의약관리잡지》가 102 편으로 가장 많으며 《세계중의약》 이 2번째, 《세계과학기술-중의약현대화》가 3 번째이며 발표 논 문이 10 편이 넘는 정기간행물로는 《중의약도보》, 《중의약문 화》, 《중국현대중약》, 《아태전통의약》, 《중국중의약현대원정교 육》, 《중국위생》, 《중국의약도보》, 《시진국의국약》순으로 중 의약 일대일로 관련 연구가 매우 중시되고 있음을 알 수 있다.

\section{5. 발표 논문수에 따른 연구자 순위}

표 2는 논문을 4편 이상 발표한 연구자들이다(원문 참고).

\section{6. 발표 논문이 4 편 이상인 기관 순위}

표 3은 발표 논문이 4편 이상인 기관들이다(원문 참고).

상해중의약대학(上海中醫藥大學)이 44 편을 발표하여 제 1 위 를 차지했는데 이는 상하이가 국제화된 도시인 것과 관련이 있 다. 세계중의약학회연합회(世界中醫藥學會聯合會)도 44편을 발표하여 제 2 위인데 이는 학회가 이름에 걸맞게 중의약 일대 일로의 전파에 적극적으로 참여하고 있기 때문이다. 호남중의 약대학(湖南中醫藥大學)은 32편을 발표하였고 특히 2017년에 집중되어 있는데 이는 본 대학이 2017년에 중의약 일대일로 연구붐이 불었기 때문이다. 그러나 2018년에는 급격히 발표논 문수가 줄어든 것을 보아 정책의 지속성이 결여된 것과 관련있 는 듯 하다. 섬서중의약대학(陕西中醫藥大學)은 30 편을 발표하 였는데 이는 대학이 실크로드라는 지형적 우세에 힘입어 최근 수년간 지속적으로 성장했음을 보여준다. 그 뒤를 이어서 북경 중의약대학(北京中醫藥大學)이 26편, 남경중의약대학(南京中醫 藥大學)이 26편, 광서중의약대학(廣西中醫藥大學)이 20편, 운 남중의학원(云南中醫學院)이 18편, 중국중의과학원(中國中醫科 學院)이 16 편, 광주중의약대학(廣州中醫藥大學)이 16 편, 호북 중의약대학(湖北中醫藥大學)이 16 편, 하남중의약대학(河南中醫 
藥大學)이 14 편, 감숙중의약대학(甘緟中醫藥大學)이 12 편을 발 표했다.

\section{7. 연도별 기관의 발표 논문수 변화}

그림 4(원문 참고).

그림 4에서 보듯이 중의약 일대일로에 관련된 논문 발표 기 관은 국내 중의약대학 등 고등교육기관과 과학연구기관이 위 주이며 민간에서는 세계중의약학회연합회가 독보적인데 이는 이 학회가 적극적으로 관련된 회의 등을 개설한 것과 관련 있 다.

\section{CiteSpace 키워드 클러스터}

그림 5 CiteSpace 키워드 클러스터.

CiteSpace는 미국 Drexel 대학의 첸차오메이(陈超美)교 수가 Java 언어 기반으로 개발한 시각화 프로그램으로 인용문 공간의 지식 클러스터와 분포를 발굴할 뿐 아니라 기타 지식 단위간- 저자, 기관, 국가간의 합작 등 그룹-의 동시등장분석 (co-occurrence analysis) 기능도 제공한다.

우리는 데이터를 예비처리하여 변환한 후 CiteSpace에 도 입하여 분석하였다.

1 년을 하나의 시간 단위(slice)로 설정하고 키워드와 저자 및 기관을 선정하여 노드(node) 유형으로 둔 다음 키워드를 삼각형으로 표시하고 기관을 원형으로 표시한 다음 연륜 방식 으로 노드의 크기를 표시하였다. 노드의 크기가 클수록 키워드 나 기관의 빈도수가 높은 것을 뜻하는데 이는 연구에 있어 중 심적 내용이나 핵심적인 논문을 발표한 기관임을 뜻한다. 연결 관계는 cosine 계산법을 이용하였고 $40 \%$ 내의 순위에 든 핵 심 노드를 선택했다. 클러스터 분석 결과 모듈값(Q value)은 0.953 이고 평균윤곽값(S value)은 0.6124이다. 일반적으로 네트워크 구조와 클러스터의 선명도에 따라 모듈값(Q value) 과 평균윤곽값(S value) 두가지 지표를 제공하며, 이는 맵의 효과를 평가하는 근거가 된다. 일반적으로 $\mathrm{Q}$ value가 ([0-1]) 구간내에서 $\mathrm{Q}>0.3$ 이면 연합의 구성이 현저함을 의미하고 S value가 0.7 이면 클러스터가 고효율이라고 믿을만 하며 0.5 이 상이면 클러스터가 합리적이라고 여겨진다. 그래서 우리는 이 클러스터 맵이 상대적으로 현저하고 믿을만한다고 여긴다.

CiteSpace의 키워드 클러스터를 통해 7대 분류를 얻을 수 있었다.

첫번째 클러스터는 “中医”를 태그로 하여 상해중의약대학, 광주중의약대학에서 복수로 데이터를 예비처리하고 전환후 CiteSpace에 도입하여 분석하였다. 불산중의원, 몰타대학중 의센터, 요녕중의약대학 등이 주도하는 중의, 공자문화 전파 를 주제로 하는 클러스터는 주로 문화전파, 중서문화교류로 연
구 방향을 잡았었는데 이는 중의약 일대일로에 관한 주요 연구 주제라 할 수 있고 그 중에서는 기회, 곤경, 사고, 표준화, 침구, 의료보험, 발전현황 등 구체적인 조작 과정 중에서의 이론적 탐구가 담겨 있다.

두번째 클러스터는 “助力”을 태그로 한 것으로 국가중의약 관리국, 광주중의약대학, 국가위생계생위 및 광동성 지방의 일 부 의약문화회사가 주도하고 있고 중의원, 중의약문화산업, 중 화민족, 중의약학, 중의약학원을 테마로 한 클러스터이다. 이 클러스터는 중국 정부와 홍콩 및 광동 지역과 홍콩의 지정학적 우위가 구축된 전파경로를 통하였다.

세번째 클러스터는 “传播”를 태그로 한 것으로 산서중의약 대학의 외국어학원, 중국중의과학원의 왕징병원, 상해중의약 대학의 재활의학원, 시드니 콩코드 군종합병원 등의 기관이 주 도하고 있으며 국제전파, 국제서비스, 국제전략, 해외중의, 다 차원 전파, 컨벤션 센터, 기자회견, 교육 등을 주제로 한 클러 스터로 주로 중부 유럽, 우크라이나 등지에서 활발히 전개되고 있다.

네번째 클러스터는 “中医药事业”을 태그로 한 것으로 운남 성중의약학회, 남성중의약관리국, 남성위생과 계획생육위원회 등이 주도하고 있으며 중의약사업, 우세병종, 전승혁신 등을 주제로 한 클러스터이다.

다섯번째 클러스터는 “传统医学”을 태그로 한 것으로 북경 대학 외국어학원, 상해중의약대학 과기인문연구원 국제화발전 연구센터, 중국중의과학원중의약정보연구소, 캐나다 온타리오 중의학원 등의 기관이 주도하고 있으며 전통의학, 국제보건기 구, 인류건강 등 거시적인 관점에서 중의약 일대일로를 연구하 고 있다.

여섯번째 클러스터는 “中医药高等教育”을 태그로 한 것으 로 광주중의약대학 마르크스주의대학, 산서중의약대학, 영하 의과대학중의(회족의학)학원, 상해외국어학원러시아동유럽중 앙아시아학원 등의 기관이 주도하고 있으며 중의약 고등교육, 인터넷 의식 진지 구축, 학과건설, 유학생 공헌 등을 연구방향 으로 잡고 있다.

일곱번째 클러스터는 “中医学”을 태그로 한 것으로 광주중 의약대학 침구재활 임상학원, 남방의과대학 중의학원 등의 기 관이 주도하고 있으며 중의학, 중의학교육, 전업핵심, 과정 교 재, 영어 교재, 중서의 결합 등을 학과 건설의 각도에서 클러스 터가 있다.

\section{9. 기관 협력 네트워크}

그림6 CiteSpace 키워드 클러스터 맵.

기관들 사이의 협력은 크게 5 개 그룹으로 나눌 수 있는데 우선 최상단 중간과 우하단에 걸쳐 있는 거대한 그룹으로 상 단 중간 부분에는 복건중의약대학, 산서중의약대학, 귀양중의 
학원, 영하의과대학, 요녕중의약대학, 장춘중의약대학, 천진중 의약대학이 그룹의 상반 부분을 구성하고 있고 이와 밀접하게 연결된 하반부에는 상해중의약대학, 중국중의과학원, 사제침 구학회연합회, 상해선다학원 경영학원과 동화대학 경영학원이 있으며 이는 중국중의과학원을 제외하고는 모두 활동지역(滑 动地区; sliding area)으로 상하이 지역의 지정학적 이점과 높 은 국제화 정도의 우위를 보여주고 있다. 그 다음은 이 그룹의 오른쪽에 위치한 호북중의약대학, 호남중의약대학, 중의약도 보잡지사(호남), 하남중의약대학, 남경중의약대학 및 호북성고 등교육인문사회과학중점연구기지 중의약발전연구센터(우한공 상학원)로 구성된 화중화남(華中華南) 지역 그룹이 있다.

그외 또 다른 그룹으로 북경중의약대학, 세계중의약회연합 회, 중국의약보건품수출입상회, 중국의학과학원 베이징협화의 학원 요용식물연구소와 중국언론대학으로 북경 그룹이다. 맨 왼쪽 하단은 광주중의약대학, 남방의과대학중의약학원, 광서 중의약대학, 운남중의학원 등 양광(兩廣)과 서남(西南) 지역의 비교적 느슨한 협력 그룹이다.

\section{0. 저자 협력 네트워크}

그림 7 저자 네트워크 맵.

4 편 이상의 논문을 발표한 저자는 총 76 명이며 10 편 이상 의 논문을 발표한 저자는 다음과 같다. 严喧喧은 20 편, 宋欣阳 은 20 편, 赵维婷은 14 편, 何清湖은 12 편, 周蔓仪는 12 편, 陈 小平은 12 편, 朱民은 10 편을 각각 발표하였다. 저자들의 상관 클러스터 맵을 보면 상위 76 명의 저자는 몇 개의 비교적 큰 그 룹을 형성하고 있는데 가령 우측에 있는 최대 그룹에는 핍. 喧, 何清湖, 胡以仁, 陈小平, 朱民, 丁颖, 魏一苇, 李红文, 刘洁, 冯雅婷이 있으며 논문 발표수가 많은 저자들로 구성되어 있다. 그 다음 그룹은 우측하단에 있으며 宋欣阳, 李海英, 市跃峰, 施 建蓉, 郑林帟, 黄祎晨, 魏浩然, 王硕로 구성되어 있다. 좌측에 여러 개의 소형 그룹중에서 비교적 큰 그룹은 모非, 左媛媛, 赵 少钦, 周青, 孙永林으로 구성되어 있다 좌측 하단 3 개의 소그 룹은 각각 刘丹, 张鹭华, 胡检生으로 구성되어 있다. 曲姗姗, 张继茾, 黄泳은 2 번째 가지 그룹을 구성하고 杨宇洋, 骆璐는 3 번째 가지 소그룹을 형성한다. 좌측 상단의 黄璐琦, 白吉庆, 省
培根, 赵立春, 唐红珍, 梁晓兰 등은 비교적 큰 1 번째 가지 그룹 을 형성한다. 좌측 중간은 章涤凡, 刘殿刚, 张晓燕, 顾赤, 毛和 荣 등이 그룹을 형성하고 있다. 그외 저자들 중 张炎과 张丽, 李欣과 储利荣, 侯冠辉와 侯荔桉, 慕秀荣과 李霞는 각각 2 인 그룹을 형성하고 있으며 나머지 저자들은 그룹을 형성하지 않 고 개인적으로 발표하고 있다.

\section{총결}

중의약 일대일로의 발전 상황을 거시적으로 바라보면 현재 이 영역의 연구방향이 백화제방(百花齊放)으로 다양하고 점차 성숙기로 접어들고 있으며 각기 나름대로의 방법론을 구사하 는 때로 보인다. 역사적으로 중의약의 국제화, 국제무역, 국제 협력을 따르는 토론이 있어 왔는데 예를 들면 선진국과 과학 연구, 약물 개발 등의 분야에서 국제협력을 전개하는 것이 있 다. 또한 중의약문화, 중국 전통문화 전파를 주요 방식으로 하 는 “저우추취(走出去)" 전략의 응용 ${ }^{13-17)}$, 동시에 중의약 고등교 육에 관한 연구 ${ }^{18-23)}$, 중의센터 건립 ${ }^{24}$ 과 중의병원의 일대일로 시역하 발전 전략 $25-27)$, 중의약 표준 강화 연구 개발 $28-31)$, 중의 약 국제서비스 무역의 발전 ${ }^{32-38)}$, 일대일로 하에서의 중의약 국 제 인재 배양이 있으며 인재 배양에는 국내 중의약 인재 배양 과 해외유학생에 대한 중의약 인재 배양이 포함된다.

현재 중의약 일대일로의 발전 방향은 상대적으로 다양하여 국가, 정부는 거시적인 관점에서 국가에서는 일대일로의 정책 적 우위에 힘입어 중의약의 해외 진출을 장려하고 지원하여 세 계 지역 경제 발전에 공헌하고 있다. 중관적인 측면에서 보면 국내 각 중의약학교와 연구기관은 현재 적극적으로 중의약 일 대일로 프로젝트를 대대적으로 개발하고 있으며 미시적인 관 점에서 보면 갈수록 많은 의료, 과학 연구, 교직원들이 중의약 일대일로 사업에 참여하고 있다.

현재 중의약계는 어떤 주체가 - 중의약 국제화 인재 양성을 하고 어떤 것을-연구 - 무역 - 의료 - 양생보건 - 문화 전파하며 왜-‘평화협력・개방포용・상학상감 - 상호이익'을 실현 하는지에 대해서 적극적으로 해결하고 있으며 중의약만이 가 지고 있는 독특한 문화 - 건강 - 의료 - 보건 등의 우세함이 반 드시 일대일로의 길에 꽃을 피울 것이라고 믿는다. 